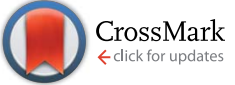

Cite this: RSC Adv., 2017, 7, 12805

Received 20th December 2016 Accepted 10th February 2017

DOI: $10.1039 / c 6 r a 28448 e$

rsc.li/rsc-advances

\title{
Trifluoromethanesulfonic acid-based DESs as extractants and catalysts for removal of DBT from model oil
}

\author{
Chunfeng Mao, Rongxiang Zhao, ${ }^{*}$ Xiuping Li and Xiaohan Gao \\ A series of deep eutectic solvents (DESs) of $\mathrm{ChCl} X \mathrm{CF}_{3} \mathrm{SO}_{3} \mathrm{H}$ ( $X$ from 1.0 to 2.0) were synthesized by \\ stirring a mixture of choline chloride $(\mathrm{ChCl})$ and trifluoromethanesulfonic acid $\left(\mathrm{CF}_{3} \mathrm{SO}_{3} \mathrm{H}\right)$ at room \\ temperature. The DESs were characterized by Fourier transform infrared (FT-IR) and ${ }^{1} \mathrm{H}$ nuclear \\ magnetic resonance $\left({ }^{1} \mathrm{H}\right.$ NMR). The oxidative desulfurization of model oil was investigated using \\ $\mathrm{ChCl} / 1.5 \mathrm{CF}_{3} \mathrm{SO}_{3} \mathrm{H}$ as a catalyst and extraction agent, and $\mathrm{H}_{2} \mathrm{O}_{2}$ as the oxidant. Some reaction \\ parameters such as type of DES, molar ratio of $\mathrm{CF}_{3} \mathrm{SO}_{3} \mathrm{H}$ and $\mathrm{ChCl}$ in $\mathrm{DESs}, \mathrm{H}_{2} \mathrm{O}_{2}$ dose, reaction \\ temperature, DES dose and type of sulfur compound were investigated. Under the optimum \\ conditions, the removal rate of dibenzothiophene (DBT) and 4,6-dimethyldibenzothiophene (4,6- \\ DMDBT) can reach up to $98.65 \%$ and $96.8 \%$, respectively. After five recycling runs, the removal rate \\ of DBT can still reach $97.16 \%$.
}

\section{Introduction}

$\mathrm{SO}_{x}$ emission, which is mainly produced by vehicles, not only pollutes the environment, such as acid rain, ${ }^{\mathbf{1}}$ but also harms the health of humans, such as cancer. In order to decrease the pollution caused by $\mathrm{SO}_{x}$, many countries have laid down a series of rules for restricting the sulfur content of fuel oil. It is an aim to achieve little sulfur in oil (sulfur content $<10 \mu \mathrm{g} \mathrm{g}^{-1}$ ). ${ }^{2}$ The traditional hydrodesulfurization (HDS) process, removing aliphatic and acyclic sulfur compounds, has been considered as a mature technology. However, HDS finds it difficult to remove aromatic sulfur compounds ${ }^{3,4}$ such as thiophene (TH), benzothiophene (BT) dibenzothiophene (DBT) and their derivatives because of their large steric hindrance. Therefore, some nonhydrodesulfurization processes, such as oxidative desulfurization (ODS), ${ }^{5}$ biodesulfurization (BDS), ${ }^{6}$ extractive desulfurization $(\mathrm{EDS})^{7}$ and adsorption desulfurization (ADS), ${ }^{8}$ etc., have attracted wide attention.

Among these non-hydrodesulfurization processes, oxidative desulfurization (ODS) was considered as one of the most promising technologies due to its advantages, ${ }^{9}$ such as the high desulfurization rate and the mild reaction conditions. Various oxidants such as $\mathrm{H}_{2} \mathrm{O}_{2}, \mathrm{NO}_{2}, \mathrm{O}_{2}, \mathrm{O}_{3}, \mathrm{~K}_{2} \mathrm{FeO}_{4}$, and organic peroxides have been investigated in the oxidative desulfurization system. Among these oxidants, $\mathrm{H}_{2} \mathrm{O}_{2}$ is widely employed due to its high activity and low price. ${ }^{\mathbf{1 0}}$

College of Chemistry, Chemical Engineering and Environmental Engineering, Liaoning Shihua University, Fushun 113001, China. E-mail: maochunfeng555@163.com; zylhzrx@126.com
In recent years, a Brønsted acid based ionic liquid was used in the oxidative desulfurization process. Fang et al. ${ }^{11}$ reported the synthesis of 1-butyl-3-methyl-imidazolium trifluoroacetic acid $\left(\left[\mathrm{C}_{4} \mathrm{mim}\right] \mathrm{TFA}\right)$ ionic liquids and their application in oxidative desulfurization and found that the anion of the ionic liquid has an important influence on the desulfurization rate. Lu et al. ${ }^{12}$ synthesized 1-methylimidazolium tetrafluoroborate $\left([\mathrm{HMIm}] \mathrm{BF}_{4}\right)$ ionic liquids and the sulfur removal of DBT in model oil can reach $93 \%$ under optimum conditions. Gao et $a l .{ }^{13}$ synthesized an acidic ionic liquid $N$-butyl- $N$-methylimidazolium hydrogen sulfate $\left([\mathrm{BMIm}] \mathrm{HSO}_{4}\right)$, its oxidative desulfurization rate can reach $100 \%$ for DBT in model oil. The $[\mathrm{BMIm}] \mathrm{HSO}_{4}$ ionic liquid can be recycled 5 times with only a slight reduction in activity. Zhao et al. ${ }^{\mathbf{1 4}}$ synthesized the Brønsted acid ionic liquid $N$-methyl-pyrrolidonium tetrafluoroborate $\left([\mathrm{Hnmp}] \mathrm{BF}_{4}\right)$ and used as the extractant and catalyst for desulfurization (ODS) of model oil. The experimental results indicated that $99.4 \%$ sulfur compounds in diesel fuel can be removed. Although these ionic liquids have better desulfurization activity in the oxidative desulfurization system, the raw materials of ionic liquids are expensive and the preparation process is complex.

As a new type of solvent, deep eutectic solvents have attracted great attention because of its excellent physical and chemical properties, which is friendly for environment. DESs are composed of two or more components that interact via intermolecular hydrogen bonds. ${ }^{15}$ Compared with the traditional ionic liquids, DESs have many advantages such as cheap and easily accessible raw material, a simple preparation process, and wide range of applications. ${ }^{16}$ In developmental history of DESs, ChCl-based DESs are first reported by Abbott and his co- 
workers, its physical properties have been researched. ${ }^{17}$ Thereafter, DESs are used in various fields such as electrochemistry, organic synthesis and separation processes. ${ }^{18-21}$ DESs also are used in the desulfurization process of fuels. For example, $\mathrm{Zhu}$ et $a l^{22}$ reported the synthesis of $\mathrm{ChCl} \cdot 2 \mathrm{CH}_{3} \mathrm{COOH}$ and it was used as the extractant of oxidation desulfurization process. The study found that the removal rate of DBT in model oil can up to 98.6\% under UV light irradiation. Gano Z. S. et al. ${ }^{23}$ reported that the $\mathrm{FeCl}_{3}$-based deep eutectic solvents for the extractive desulfurization of liquid fuels. Experimental results show the desulfurization efficiencies of $64 \%$ and $44 \%$ can be achieved for DBT and thiophene, respectively. Yin et al. ${ }^{24}$ reported that the synthesis of $\mathrm{ChCl} / p$-TsOH and the desulfurization efficiencies of $\mathrm{ChCl} / p$-TsOH can reach up to $97.25 \%$, which are much higher than those obtained with traditional and functional ionic liquids. Our research group has synthesized phenylpropanoic acid-based DESs and was applied to the oxidation desulfurization process. $^{25}$ In the synthesis, the acid-based DESs was synthesized by heating method. As is known to all, simpler preparation process and higher acidity of DESs are favorable for the desulfurization. ${ }^{26}$ Therefore, it is necessary to develop a new DES using a simple preparation method and apply it to the oxidative desulfurization process.

Trifluoromethanesulfonic acid $\left(\mathrm{CF}_{3} \mathrm{SO}_{3} \mathrm{H}\right)$ is one of the strongest organic acids, it is widely used in the synthesis reaction. In this work, the novel $\mathrm{CF}_{3} \mathrm{SO}_{3} \mathrm{H}$-based DESs were synthesized by stirring a mixture of $\mathrm{ChCl}$ and $\mathrm{CF}_{3} \mathrm{SO}_{3} \mathrm{H}$ at the room temperature. The removal rate of DBT from model oil was investigated using $\mathrm{CF}_{3} \mathrm{SO}_{3} \mathrm{H}$-based DESs as an extraction agent and catalyst, $\mathrm{H}_{2} \mathrm{O}_{2}$ as the oxidant. The influence of different type DESs, the molar ratio of $\mathrm{ChCl}$ to $\mathrm{CF}_{3} \mathrm{SO}_{3} \mathrm{H}$, the oxygen to sulfur $(\mathrm{O} / \mathrm{S})$ molar ratio, the reaction temperature and the amount of DESs on the desulfurization rate was investigated. Under the optimum conditions, the removal rate of dibenzothiophene (DBT) and 4,6-dimethyldibenzothiophene (4,6-DMDBT) can reach up to $98.65 \%$ and $96.8 \%$, respectively. After five recycling runs, the removal rate of DBT can still reach $97.16 \%$.

\section{Experimental}

\subsection{Chemical regent and instrument}

Dibenzothiophene (DBT, 98\%), benzothiophene (BT, 97\%), thiophene ( $\mathrm{TH}, 99.8 \%)$ and 4,6-dimethyldibenzothiophene (4,6-DMDBT, 97\%) were purchased from Aladdin Chemistry Co. Ltd. The choline chloride ( $\mathrm{ChCl}, \mathrm{AR})$, tetrabutylammonium chloride (TBAC, AR), tetraethylammonium chloride (TEAC, AR), n-octane, carbon tetrachloride $\left(\mathrm{CCl}_{4}, 99.5 \%\right)$, trifluoromethanesulfonic acid $\left(\mathrm{CF}_{3} \mathrm{SO}_{3} \mathrm{H}, 98 \%\right)$, and hydrogen peroxide $\left(\mathrm{H}_{2} \mathrm{O}_{2}, 30 \mathrm{wt} \%\right)$ were purchased from Sinopharm
Chemical Reagent Co. Ltd. Gas chromatography was carried out on an Agilent 7890A GC with an FID detector using a $30 \mathrm{~m}$ packed HP5 column. Infrared spectra of DBT, oxidation of DBT, DESs and raw materials were determined on Fouriertransform infrared spectrometer (WQF-520; Beijing Beifen Ruili Instrument Company, China). ${ }^{1} \mathrm{H}$ NMR of DESs were determined by using the Mercury Plus $400 \mathrm{MHz}$ spectrometer (Varian Co., Ltd. American).

\subsection{Synthesis of $\mathrm{ChCl} / \mathrm{XCF}_{3} \mathrm{SO}_{3} \mathrm{H}$}

$\mathrm{ChCl} / \mathrm{XCF}_{3} \mathrm{SO}_{3} \mathrm{H}$ was synthesized by stirring a mixing of $\mathrm{ChCl}$ and $\mathrm{CF}_{3} \mathrm{SO}_{3} \mathrm{H}$ at room temperature. The specific process is as follows: $\mathrm{ChCl}$ was added to a $100 \mathrm{~mL}$ round-bottomed flask. Then, the $\mathrm{CF}_{3} \mathrm{SO}_{3} \mathrm{H}$ was carefully added according to a certain molar ratio under stirring conditions. The two raw materials were stirred vigorously for $1 \mathrm{~h}$ in order to fully release the reaction heat. After the reaction, the $\mathrm{ChCl} / X \mathrm{CF}_{3} \mathrm{SO}_{3} \mathrm{H}(X$ from 1.0 to 2.0) DESs homogeneous liquid was obtained. The reaction was shown in Fig. 1. TBAC/ $\mathrm{CF}_{3} \mathrm{SO}_{3} \mathrm{H}$ and TEAC/CF $\mathrm{SO}_{3} \mathrm{H}$ were synthesized according to the same method.

${ }^{1} \mathrm{H}$ NMR spectra of $\mathrm{CF}_{3} \mathrm{SO}_{3} \mathrm{H}, \mathrm{ChCl}$ and $\mathrm{ChCl} / \mathrm{CF}_{3} \mathrm{SO}_{3} \mathrm{H}$ were obtained on hydrogen spectrum detector. Coupling constants (J1) in $\mathrm{Hz}$ and chemical shifts (d) are given in ppm. The multiplicities of signals in ${ }^{1} \mathrm{H}$ NMR are given with chemical shifts $(\mathrm{s}=$ singlet, $\mathrm{d}=$ doublet, $\mathrm{t}=$ triplet, $\mathrm{q}=$ quartet, $\mathrm{m}=$ multiplet), and the data are listed as follows:

$\mathrm{CF}_{3} \mathrm{SO}_{3} \mathrm{H}$ for ${ }^{1} \mathrm{H}$ NMR (500 MHz, $\left.\mathrm{D}_{2} \mathrm{O}\right) \delta 4.86(\mathrm{~s}, 1 \mathrm{H})$.

ChCl for ${ }^{1} \mathrm{H}$ NMR (500 MHz, $\left.\mathrm{D}_{2} \mathrm{O}\right) \delta 4.71(\mathrm{~d}, 26 \mathrm{H}), 4.08(\mathrm{~m}$, $59 \mathrm{H}$ ), 3.56-3.46 (m, 39H), 3.25 (s, $J=68.7 \mathrm{~Hz}, 30 \mathrm{H}), 3.18$ (d, $176 \mathrm{H}), 3.03(\mathrm{~s}, 2 \mathrm{H})$.

$\mathrm{ChCl} / \mathrm{CF}_{3} \mathrm{SO}_{3} \mathrm{H}$ for ${ }^{1} \mathrm{H}$ NMR (500 MHz, $\left.\mathrm{D}_{2} \mathrm{O}\right) \delta 4.77(\mathrm{~s}, 2 \mathrm{H})$, $3.90(\mathrm{ddd}, J=7.7,5.3,2.8 \mathrm{~Hz}, 1 \mathrm{H}), 3.35(\mathrm{dd}, J=5.8,4.2 \mathrm{~Hz}, 1 \mathrm{H})$, $3.04(\mathrm{~s}, 5 \mathrm{H})$.

\subsection{Desulfurization experiment}

The $500 \mu \mathrm{g} \mathrm{g}^{-1}$ model oil was prepared by dissolving $1.437 \mathrm{~g}$ DBT in $500 \mathrm{~mL} n$-octane. The model oil, DESs, and $30 \mathrm{wt} \% \mathrm{H}_{2} \mathrm{O}_{2}$ were added into a three-necked flask. The mixture was stirred in a water bath at a certain temperature. A small amount of the upper oil phase was removed every $20 \mathrm{~min}$ and determined by gas chromatography. The desulfurization rate was calculated using the following formula:

$$
\text { ODS rate }=\frac{S_{\text {tot }}-S_{\text {res }}}{S_{\text {tot }}} \times 100 \%
$$

where $S_{\text {tot }}\left(500 \mu \mathrm{g} \mathrm{g}^{-1}\right)$ is the initial concentration of the sulfur compound in the model oil and $S_{\text {res }}$ is the residual concentration of the sulfur compound after the ODS process.

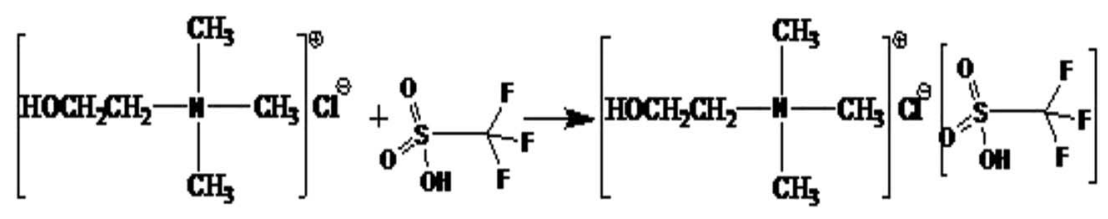

Fig. 1 Synthetic mechanism of DESs. 


\section{Results and discussion}

\subsection{Characterization}

3.1.1 Infrared spectra analysis. The infrared spectra of $\mathrm{ChCl}, \mathrm{CF}_{3} \mathrm{SO}_{3} \mathrm{H}$ and $\mathrm{ChCl} / 1.5 \mathrm{CF}_{3} \mathrm{SO}_{3} \mathrm{H}$ were shown in Fig. 2. Compared with the peaks of $\mathrm{ChCl}$ and $\mathrm{CF}_{3} \mathrm{SO}_{3} \mathrm{H}$, the stretching vibration peak of $\mathrm{O}-\mathrm{H}$ at $3272 \mathrm{~cm}^{-1}$, stretching vibration peak of $\mathrm{C}-\mathrm{H}$ at $3018 \mathrm{~cm}^{-1}$ and stretching vibration peak of $\mathrm{S}=\mathrm{O}$ at $1406 \mathrm{~cm}^{-1}$ in $\mathrm{ChCl}$, and stretching vibration peak of $\mathrm{F}-\mathrm{C}$ at 947 $\mathrm{cm}^{-1}$ and bending vibration peak of $\mathrm{F}-\mathrm{C}$ at $621 \mathrm{~cm}^{-1}$ in $\mathrm{CF}_{3} \mathrm{SO}_{3} \mathrm{H}$ shift to $3466,3048,1416,960$ and $644 \mathrm{~cm}^{-1}$ in $\mathrm{ChCl} /$ $1.5 \mathrm{CF}_{3} \mathrm{SO}_{3} \mathrm{H}$ were clearly seen (Fig. 2). The peaks happening to shift are attribute to the formation of hydrogen bond in the DES. $^{27}$

3.1.2 ${ }^{1} \mathbf{H}$ NMR characterization. In order to further confirm the interactions between $\mathrm{ChCl}$ and $\mathrm{CF}_{3} \mathrm{SO}_{3} \mathrm{H},{ }^{1} \mathrm{H}$ NMR spectra of $\mathrm{CF}_{3} \mathrm{SO}_{3} \mathrm{H}, \mathrm{ChCl}$ and DESs were obtained in Fig. 3. The ${ }^{1} \mathrm{H}$ NMR spectra of $\mathrm{ChCl} / 1.5 \mathrm{CF}_{3} \mathrm{SO}_{3} \mathrm{H}$ in Fig. 3(c), the peak of hydrogen bond obviously became stronger and slightly shift to right compare with $\mathrm{ChCl}$ in Fig. 3(b). ${ }^{1} \mathrm{H}$ NMR spectra of $\mathrm{CF}_{3} \mathrm{SO}_{3} \mathrm{H}$ demonstrate there is a peak of hydrogen bond in Fig. 3(a). The

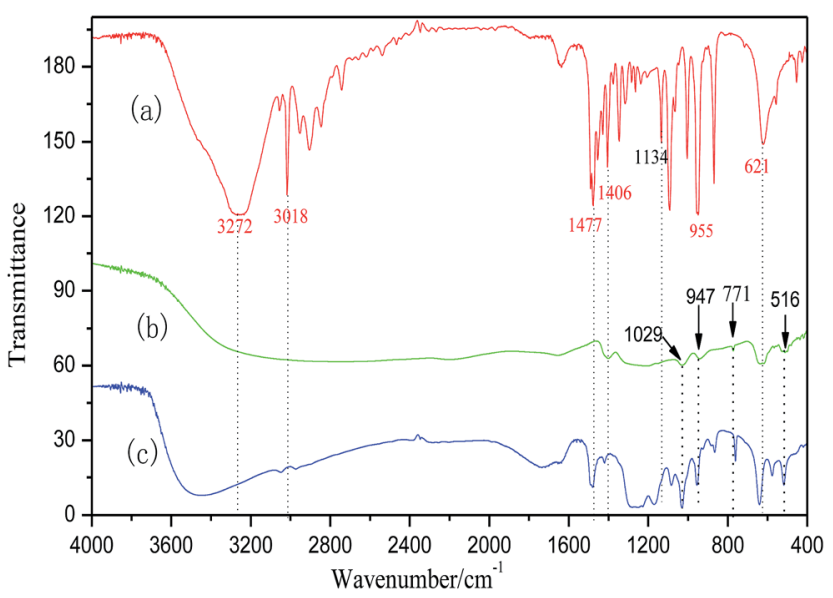

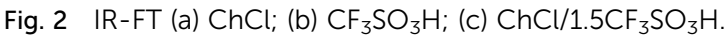

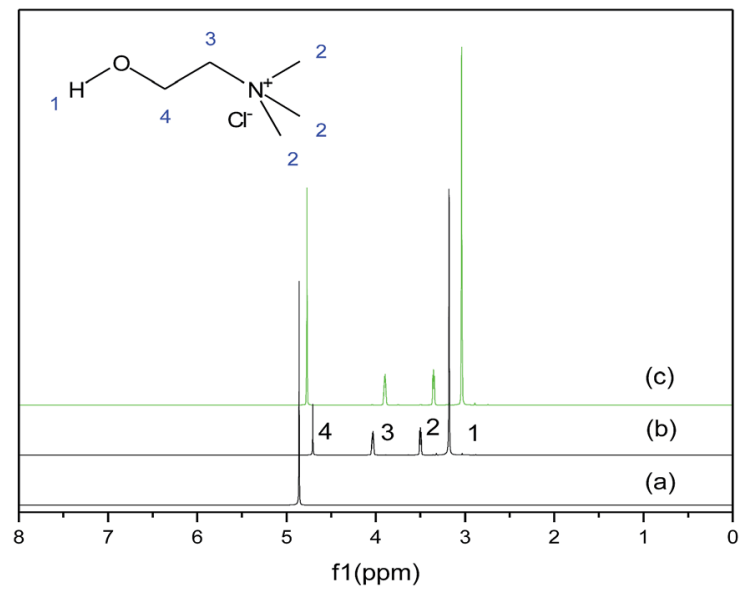

Fig. $3{ }^{1} \mathrm{H}$ NMR spectra of (a) $\mathrm{CF}_{3} \mathrm{SO}_{3} \mathrm{H}$; (b) $\mathrm{ChCl}$; (c) $\mathrm{ChCl} / 1.5 \mathrm{CF}_{3} \mathrm{SO}_{3} \mathrm{H}$. peak of ChCl labeled " 4 " and the peak of hydrogen bond in $\mathrm{CF}_{3} \mathrm{SO}_{3} \mathrm{H}$ disappeared and there is a new peak of hydrogen bond appeared in $\mathrm{ChCl} / 1.5 \mathrm{CF}_{3} \mathrm{SO}_{3} \mathrm{H}$. These results demonstrate that there are formation of hydrogen bond between $\mathrm{ChCl}$ and $\mathrm{CF}_{3} \mathrm{SO}_{3} \mathrm{H}^{22}$

\subsection{Oxidative desulfurization reaction conditions}

3.2.1 Desulfurization rate of different desulfurization system. In this study, the removal rate of DBT in desulfurization system of $\mathrm{ChCl} / \mathrm{CF}_{3} \mathrm{SO}_{3} \mathrm{H}, \mathrm{TBAC} / \mathrm{CF}_{3} \mathrm{SO}_{3} \mathrm{H}$ and $\mathrm{TEAC} / \mathrm{CF}_{3} \mathrm{SO}_{3} \mathrm{H}$ was investigated. The results are shown in Fig. 4(a). It can be seen from Fig. 4(a), the desulfurization rate of DBT reached $90.58 \%$ for $\mathrm{ChCl} / \mathrm{CF}_{3} \mathrm{SO}_{3} \mathrm{H}, 41.54 \%$ for $\mathrm{TBAC} / \mathrm{CF}_{3} \mathrm{SO}_{3} \mathrm{H}$ and $85.38 \%$ for $\mathrm{TEAC} / \mathrm{CF}_{3} \mathrm{SO}_{3} \mathrm{H}$ after the $180 \mathrm{~min}$, respectively. The difference of desulfurization rate may be due to the difference in steric hindrance of DESs. It is well known that the steric hindrance of DESs follow the order TBAC $/ \mathrm{CF}_{3} \mathrm{SO}_{3} \mathrm{H}>$ TEAC/ $\mathrm{CF}_{3} \mathrm{SO}_{3} \mathrm{H}>\mathrm{ChCl} / \mathrm{CF}_{3} \mathrm{SO}_{3} \mathrm{H}$. The order of desulfurization rate with these DESs is $\mathrm{ChCl} / \mathrm{CF}_{3} \mathrm{SO}_{3} \mathrm{H}>\mathrm{TEAC} / \mathrm{CF}_{3} \mathrm{SO}_{3} \mathrm{H}>\mathrm{TBAC} /$ $\mathrm{CF}_{3} \mathrm{SO}_{3} \mathrm{H}$. The research shows that the bigger steric hindrance of long cation chain is not conducive to the oxidative desulfurization. ${ }^{28}$ Four cation chains of $\mathrm{TBAC}^{2} \mathrm{CF}_{3} \mathrm{SO}_{3} \mathrm{H}$ are the longest, therefore its steric hindrance is the biggest result in lowest desulfurization rate. Four cation chains of $\mathrm{ChCl}$ / $\mathrm{CF}_{3} \mathrm{SO}_{3} \mathrm{H}$ was the shortest, so the its steric hindrance is the smallest result in the highest desulfurization rate. Therefore, $\mathrm{ChCl} / \mathrm{CF}_{3} \mathrm{SO}_{3} \mathrm{H}$ was chosen as the catalyst and extractant for the system of oxidation desulfurization.

3.2.2 Influence of acidity of DESs on desulfurization rate. $\mathrm{ChCl} / \mathrm{XCF}_{3} \mathrm{SO}_{3} \mathrm{H}$ were synthesized using $\mathrm{CF}_{3} \mathrm{SO}_{3} \mathrm{H}$ and $\mathrm{ChCl}$ as raw materials. A series of $\mathrm{ChCl} / \mathrm{XCF}_{3} \mathrm{SO}_{3} \mathrm{H}$ ( $X$ from 1.0 to 2.0) with different acidity were investigated by changing the molar ratio of $\mathrm{ChCl}$ to $\mathrm{CF}_{3} \mathrm{SO}_{3} \mathrm{H}$. As shown in Fig. 4(b), the desulfurization rate obviously increased from $90.58 \%$ to $98.85 \%$ when the molar ratio of $\mathrm{CF}_{3} \mathrm{SO}_{3} \mathrm{H}$ to $\mathrm{ChCl}$ were increased from 1 to 1.5. However, the desulfurization rate dropped from $98.85 \%$ to $87.3 \%$ when the molar ratio of $\mathrm{CF}_{3} \mathrm{SO}_{3} \mathrm{H}$ to $\mathrm{ChCl}$ was increased to 2. It is because that acidity of DESs is too strong when the molar ratio of $\mathrm{CF}_{3} \mathrm{SO}_{3} \mathrm{H}$ to $\mathrm{ChCl}$ was increased to 2 . It could be attributed to the higher acidity rapidly decomposed $\mathrm{H}_{2} \mathrm{O}_{2}$ into oxygen, thereby decrease the oxidative ability of the system. ${ }^{29}$ The highest desulfurization rate of $98.85 \%$ can be attached when the molar ratio of $\mathrm{ChCl}$ to $\mathrm{CF}_{3} \mathrm{SO}_{3} \mathrm{H}$ is 1.5. Moreover, the viscosity of DESs have important influence on desulfurization, the high viscosity of DESs decrease extractive ability of DESs. ${ }^{30}$ The high conductivity show there are a lot of ions in DESs. ${ }^{12}$ Therefore, high conductivity is benefit for desulfurization. As shown in Table 1, the conductivity and viscosity of DESs decrease with increasing molar ratio of $\mathrm{CF}_{3} \mathrm{SO}_{3} \mathrm{H}$ to $\mathrm{ChCl}$. The consideration for influence of acidity, the conductivity and the viscosity of DESs on desulfurization, $\mathrm{ChCl} / 1.5 \mathrm{CF}_{3} \mathrm{SO}_{3} \mathrm{H}$ can be selected as extractant and catalyst in the desulfurization system.

3.2.3 Influence of $\mathrm{O} / \mathrm{S}$ molar ratio on desulfurization rate. Amount of $\mathrm{H}_{2} \mathrm{O}_{2}$ has an important influence on the desulfurization rate. The removal of DBT from the model oil in the $\mathrm{ChCl} /$ $1.5 \mathrm{CF}_{3} \mathrm{SO}_{3} \mathrm{H}-\mathrm{H}_{2} \mathrm{O}_{2}$ system with various $\mathrm{O} / \mathrm{S}$ molar ratio was 

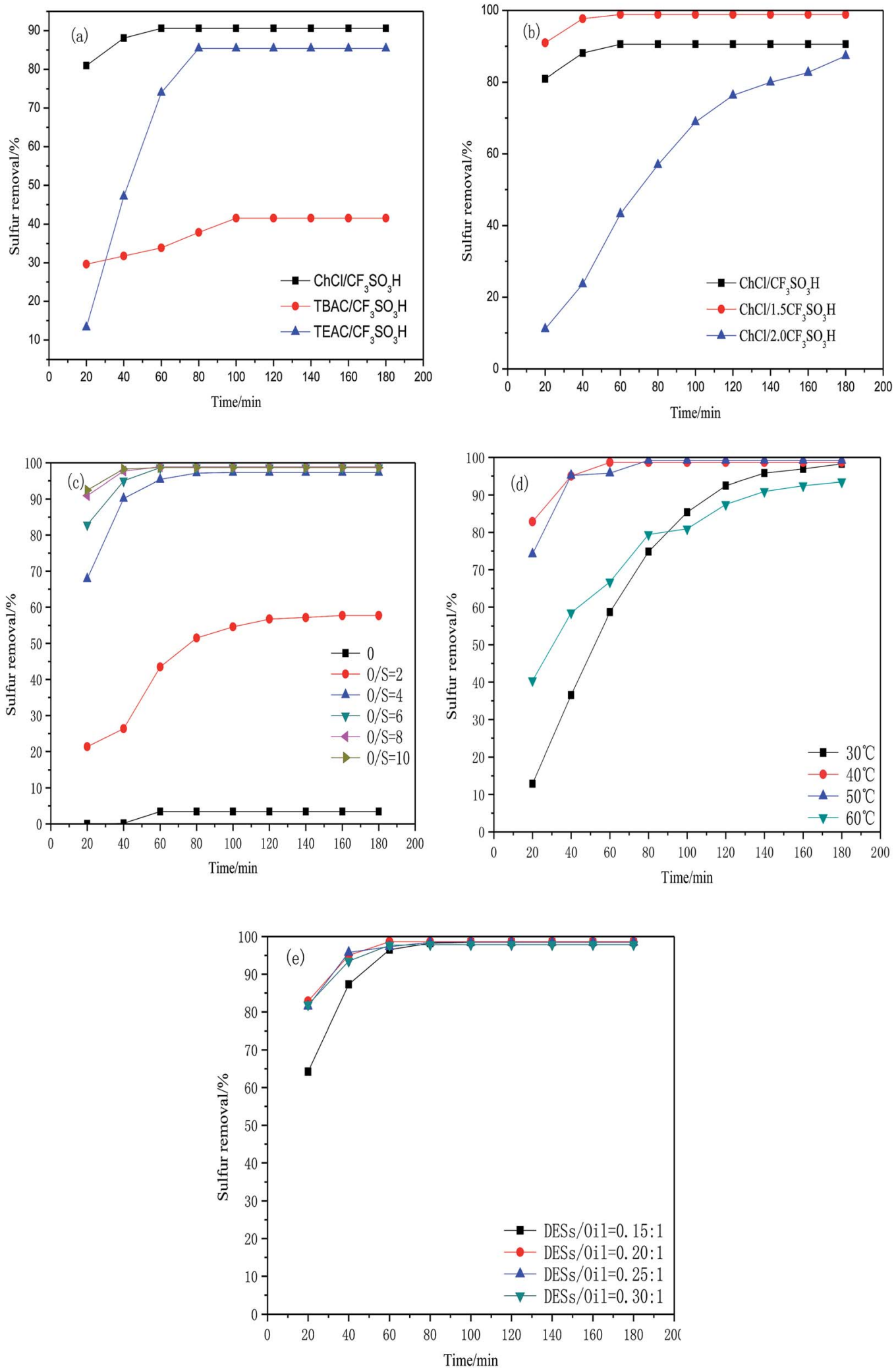

Fig. 4 (a) Influence of different type DESs on desulfurization rate $\left(5 \mathrm{~mL}\right.$ model oil, $\mathrm{O} / \mathrm{S}$ molar ratio of $\left.8,1 \mathrm{~mL} \mathrm{DESs}, 40{ }^{\circ} \mathrm{C}\right)$; (b) influence of different acidity DESs on desulfurization rate $\left(5 \mathrm{~mL}\right.$ model oil, $\mathrm{O} / \mathrm{S}$ molar ratio of $8,1 \mathrm{~mL} \mathrm{DESs}, 40{ }^{\circ} \mathrm{C}$ ); (c) influence of amount of $\mathrm{H}_{2} \mathrm{O}_{2}$ on desulfurization rate $\left(5 \mathrm{~mL}\right.$ model oil, $1 \mathrm{~mL}$ DESs, $\left.40^{\circ} \mathrm{C}\right)$; (d) influence of reaction temperature on desulfurization rate $(5 \mathrm{~mL} \mathrm{model}$ oil, $\mathrm{O} / \mathrm{S} \mathrm{molar}$ ratio of $6,1 \mathrm{~mL}$ DESs); (e) influence of amount of DESs on desulfurization rate $\left(5 \mathrm{~mL}\right.$ model oil, $\mathrm{O} / \mathrm{S}$ molar ratio of $6,40{ }^{\circ} \mathrm{C}$ ). 
Table 1 Conductivity and viscosity of DESs at $25^{\circ} \mathrm{C}$

\begin{tabular}{lll}
\hline DESs & $\begin{array}{l}\text { Conductivity } \\
(\delta) /\left(\mu \mathrm{s} \mathrm{cm}{ }^{-1}\right)\end{array}$ & $\begin{array}{l}\text { Viscosity }(\eta) / \\
(\mathrm{mPa} \mathrm{s})\end{array}$ \\
\hline $\mathrm{ChCl} / 1.0 \mathrm{CF}_{3} \mathrm{SO}_{3} \mathrm{H}$ & 5200 & 100 \\
$\mathrm{ChCl} / 1.5 \mathrm{CF}_{3} \mathrm{SO}_{3} \mathrm{H}$ & 4200 & 85 \\
$\mathrm{ChCl} / 2.0 \mathrm{CF}_{3} \mathrm{SO}_{3} \mathrm{H}$ & 4000 & 70
\end{tabular}

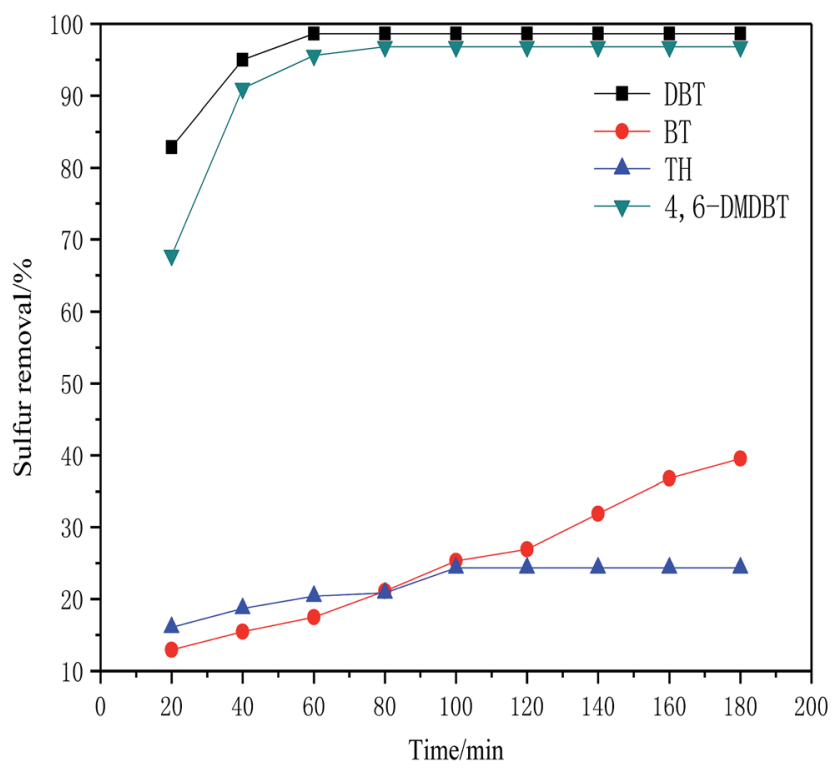

Fig. 5 Influence of different sulfur compounds on desulfurization rate ( $5 \mathrm{~mL}$ model oil, $\mathrm{O} / \mathrm{S}$ molar ratio of $6,1 \mathrm{~mL} \mathrm{DESs}, 40^{\circ} \mathrm{C}$ ).

investigated. As shown in Fig. 4(c), removal rate of DBT is only $3.42 \%$ in the absence of $\mathrm{H}_{2} \mathrm{O}_{2}$. When the hydrogen peroxide was added into the oxidative desulfurization system, the desulfurization rate obviously increases. The desulfurization rate increased from $57.69 \%$ to $98.65 \%$ when $\mathrm{O} / \mathrm{S}$ was increased from 2 to 6. According to stoichiometry, 2 molar $\mathrm{H}_{2} \mathrm{O}_{2}$ can transform 1 molar DBT to $\mathrm{DBTO}_{2}$. However, the removal rate of DBT is only $66.1 \%$ with $\mathrm{O} / \mathrm{S}$ molar ratio of 2 . The reasons are the decomposition of $\mathrm{H}_{2} \mathrm{O}_{2} \cdot{ }^{31}$ When the $\mathrm{O} / \mathrm{S}$ molar ratio is 4 , the desulfurization rate can attach to $96.4 \%$ and continue to increase the $\mathrm{O} / \mathrm{S}$ ratio, desulfurization rate increase slightly. So, the $\mathrm{O} / \mathrm{S}$ molar ratio of 6 was the optimal choice.

3.2.4 Influence of reaction temperature on desulfurization rate. The reaction temperature is also an important factor influencing oxidative desulfurization. As shown in Fig. 4(d), the reaction rate of desulfurization was obviously increased and removal rate of DBT increase from $98.27 \%$ to $98.65 \%$ when the reaction temperature increased from $30{ }^{\circ} \mathrm{C}$ to $40{ }^{\circ} \mathrm{C}$. However, the desulfurization rate no longer increased when the reaction temperature was beyond $40{ }^{\circ} \mathrm{C}$. It could be attributed to high temperature accelerate the decomposition of $\mathrm{H}_{2} \mathrm{O}_{2},{ }^{32}$ which decrease oxidative ability in the oxidative desulfurization process. So, the optimal temperature in the oxidative desulfurization system is $40{ }^{\circ} \mathrm{C}$.

3.2.5 Influence of volume ratio of DESs/oil on desulfurization rate. Fig. 4(e) illustrates the DESs dosage has an important influence on removal of DBT. The removal rate for DBT was increased from $98.46 \%$ to 98.65 when the volume ratio of DESs/oil increased from 0.15 to 0.2. Continue to increase the DESs/oil ratio, removal rate of DBT no longer increase. So, it can be concluded that the optimal volume ratio of DESs/oil is 0.2 in the desulfurization system.

3.2.6 Influence of different sulfur compounds on desulfurization rate. In this study, DBT in model oil could be effectively removed using $\mathrm{ChCl} / 1.5 \mathrm{CF}_{3} \mathrm{SO}_{3} \mathrm{H}$ as the catalyst and extractant, with $\mathrm{H}_{2} \mathrm{O}_{2}$ as the oxidant. In order to determine the desulfurization efficiency of the $\mathrm{ChCl} / 1.5 \mathrm{CF}_{3} \mathrm{SO}_{3} \mathrm{H}$ for other organic sulfides in fuels, such as 4,6-DMDBT, BT and TH were researched in oxidation desulfurization under identical conditions. The results are shown in Fig. 5. The removal rate of BT, DBT, 4,6-DMDBT and TH were $39.53 \%, 98.65 \%, 96.8 \%$ and $24.35 \%$ after $180 \mathrm{~min}$, respectively. The removal rate of four sulfur compound in the desulfurization system followed the order DBT $>4,6-\mathrm{DMBT}>\mathrm{BT}>\mathrm{TH}$. The desulfurization rate is related to the electron density of the sulfur atoms in organic sulfide. The electron cloud densities of these compounds are 5.758 for DBT, 5.760 for 4,6-DMDBT, 5.739 for BT, and 5.696 for $\mathrm{TH},{ }^{33,34}$ respectively. The electron cloud densities of 4,6-DMDBT and DBT are very approximation. However, removal rate for DBT was higher than 4,6-DMDBT due to the steric hindrance of the methyl substituent in 4,6-DMDBT. ${ }^{35}$ Therefore, the removal rate of 4,6-DMDBT is a little lower than DBT.

According to the experimental results, $\mathrm{ChCl} / 1.5 \mathrm{CF}_{3} \mathrm{SO}_{3} \mathrm{H}$ show excellent oxidative desulfurization activity. Table 2 shows a comparison of the desulfurization activity of $\mathrm{ChCl} /$ $1.5 \mathrm{CF}_{3} \mathrm{SO}_{3} \mathrm{H}$ and other acidic ionic liquids. It can be seen that $\mathrm{ChCl} / 1.5 \mathrm{CF}_{3} \mathrm{SO}_{3} \mathrm{H}$ has a high desulfurization rate under mild experimental conditions. Furthermore, $\mathrm{ChCl} / 1.5 \mathrm{CF}_{3} \mathrm{SO}_{3} \mathrm{H}$ can be prepared by a simple method and the raw material are easily obtained.

Table 2 Comparison of the desulfurization activity of $\mathrm{ChCl} / 1.5 \mathrm{CF}_{3} \mathrm{SO}_{3} \mathrm{H}$ and other acidic ionic liquids

\begin{tabular}{|c|c|c|c|c|}
\hline Catalysts & $\mathrm{S}$ content $\left(\mu \mathrm{g} \mathrm{g}^{-1}\right)$ & Reaction conditions & $\begin{array}{l}\text { Removal } \\
\text { of DBT }\end{array}$ & Ref. \\
\hline$\left[\mathrm{C}_{4} \mathrm{mim}\right] \mathrm{TFA}$ & 202 & $\mathrm{IL}:$ oil $=1: 35, \mathrm{H}_{2} \mathrm{O}_{2}=1 \mathrm{~mL}, 70{ }^{\circ} \mathrm{C}, 30 \mathrm{~min}$ & $100 \%$ & 20 \\
\hline$[\mathrm{HMIm}] \mathrm{BF}_{4}$ & 1000 & $\mathrm{IL}:$ oil $=5: 3.2, \mathrm{O} / \mathrm{S}=10,90^{\circ} \mathrm{C}, 360 \mathrm{~min}$ & $93 \%$ & 21 \\
\hline$[\mathrm{BMIM}]\left[\mathrm{HSO}_{4}\right]$ & 1000 & $\mathrm{IL}:$ oil $=1: 2, \mathrm{O} / \mathrm{S}=5,25^{\circ} \mathrm{C}, 90 \mathrm{~min}$ & $99.6 \%$ & 22 \\
\hline$[\mathrm{Hnmp}] \mathrm{BF}_{4}$ & 1550 & $\mathrm{IL}:$ oil $=1: 1, \mathrm{O} / \mathrm{S}=3,60^{\circ} \mathrm{C}, 60 \mathrm{~min}$ & $100 \%$ & 23 \\
\hline $\mathrm{ChCl} / 1.5 \mathrm{CF}_{3} \mathrm{SO}_{3} \mathrm{H}$ & 500 & $\mathrm{IL}:$ oil $=1: 5, \mathrm{O} / \mathrm{S}=6,40^{\circ} \mathrm{C}, 60 \mathrm{~min}$ & $98.65 \%$ & This \\
\hline
\end{tabular}




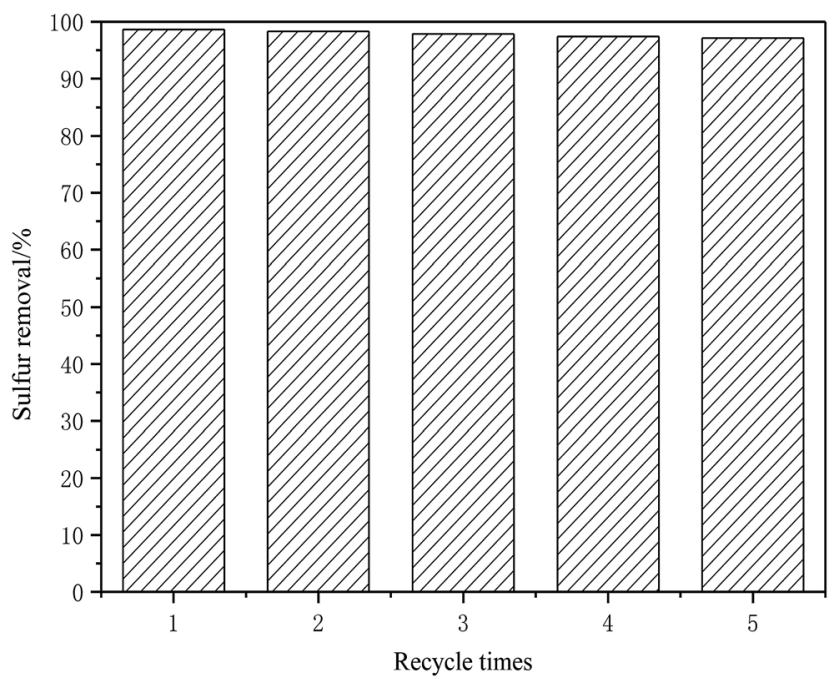

Fig. 6 Recovery and regeneration of DESs $(5 \mathrm{~mL}$ model oil, O/S molar ratio of $6,1 \mathrm{~mL} \mathrm{DESs,} 40^{\circ} \mathrm{C}$ ).

3.2.7 Recovery and regeneration of DESs. After the oxidative desulfurization reaction, the upper oil phase was removed by using a separating funnel. The water in the DESs was removed by rotary evaporation. The DESs were extracted three times using $\mathrm{CCl}_{4}$ of equal volume. Fresh $\mathrm{H}_{2} \mathrm{O}_{2}$, recovered DESs were added into model oil under the optimal conditions. As shown in Fig. 6, the removal rate of DBT decreased from $98.65 \%$ to $97.16 \%$ after five recycles. Two reasons result in the decrease of desulfurization rate. On the one hand, it could be attributed to minimal loss in DESs during the recovery process; on the other hand, it might be attributed to a little of residual oxidation products of sulfide in the recovered DESs.

3.2.8 FT-IR characterization of oxidative production. As shown in Fig. 7(a), the mixture of oil phase and DESs phase is transparent liquid before the desulfurization reaction. However, there is white precipitate between oil and DESs after the desulfurization reaction in Fig. 7(a). In order to identify the white precipitate, a reverse extraction experiment was carried out using carbon tetrachloride $\left(\mathrm{CCl}_{4}\right)$ as the extraction agent and the DESs as the extraction phase at room temperature. It

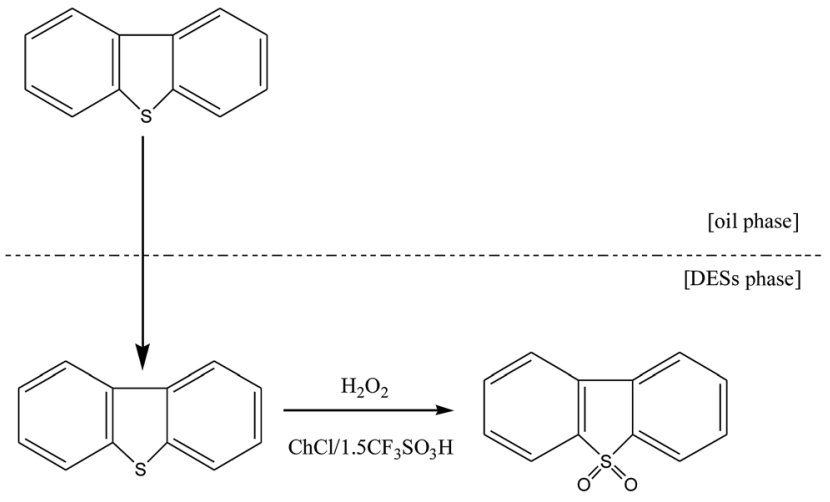

Fig. 8 Mechanism of oxidative desulfurization.

can be found that the white substance is quickly dissolved into carbon tetrachloride. After the carbon tetrachloride were remove by distillation, the white powder was obtained. The infrared analysis of the white powder is shown in Fig. 7(b). Three infrared absorption peaks are observed at 1166, 1047, and $1288 \mathrm{~cm}^{-1}$ corresponding to the three characterization peaks of $\mathrm{DBTO}_{2} \cdot{ }^{36,37}$ This shows that the DBT was oxidized to $\mathrm{DBTO}_{2}$ in the oxidative desulfurization system.

3.2.9 Mechanism of catalytic oxidative desulfurization. As seen in Fig. 8, $\mathrm{H}_{2} \mathrm{O}_{2}$ is a strong oxidant in the acidic medium. DBT was extracted into the DESs phase and was oxidized to $\mathrm{DBTO}_{2}$ under the action of $\mathrm{ChCl} / 1.5 \mathrm{CF}_{3} \mathrm{SO}_{3} \mathrm{H}$ and $\mathrm{H}_{2} \mathrm{O}_{2}$. During oxidative desulfurization process, DESs acted as not only extractant but also catalyst, so a continuous decrease of the content of DBT in n-octane was observed until $\mathrm{H}_{2} \mathrm{O}_{2}$ was completely decomposed.

\subsection{Catalytic oxidative desulfurization of diesel oil}

The S-removal activity of $\mathrm{ChCl} / 1.5 \mathrm{CF}_{3} \mathrm{SO}_{3} \mathrm{H}$ for the real diesel oil with a total S-content of $375 \mathrm{mg} \mathrm{L}^{-1}$ was also investigated. Under the optimal condition, the desulfurization rate of $68.5 \%$ was obtained. Sulfur removal efficiency was found to be lower in diesel oil than that obtained in model oil (98.65\%), which may be attributed to the more complex chemical composition of diesel. ${ }^{38}$
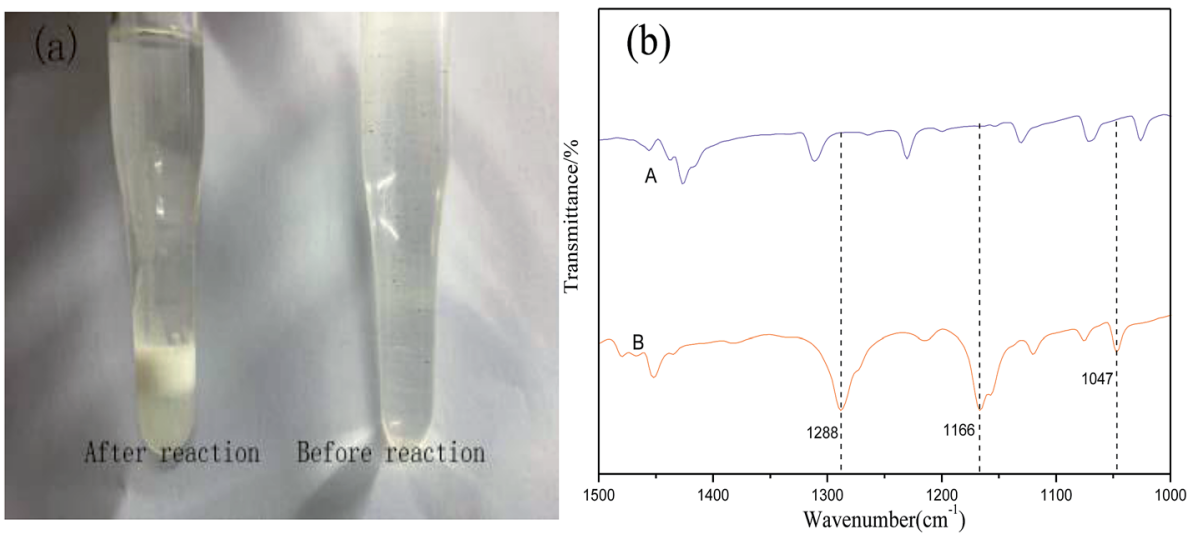

Fig. 7 (a) Contrast diagram of before and after reaction; (b) FTIR characterization of oxidative production (A) DBT, (B) DBTO 2 . 


\section{Conclusion}

A series of $\mathrm{ChCl} / X \mathrm{CF}_{3} \mathrm{SO}_{3} \mathrm{H}$ ( $X$ from 1.0 to 2.0 ) were synthesized by stirring a mixture of $\mathrm{ChCl}$ and $\mathrm{CF}_{3} \mathrm{SO}_{3} \mathrm{H}$. The DESs were used as extractant and catalyst in the oxidative desulfurization process. Compared to other acidic ionic liquids, the synthesis method of $\mathrm{ChCl} / X \mathrm{CF}_{3} \mathrm{SO}_{3} \mathrm{H}$ is simple. The $\mathrm{ChCl} / 1.5 \mathrm{CF}_{3} \mathrm{SO}_{3} \mathrm{H}$ exhibits a high desulfurization activity for DBT in model oil and can be recycled 5 times without a significant decrease in activity. The results demonstrate the DESs exhibit the high catalytic activity and stability for the desulfurization system.

\section{Acknowledgements}

The authors also acknowledge the financial support of the Natural Science Foundation of China (Project no. 21003069); the authors also acknowledge the financial support of the Doctoral Fund of Liaoning Province (201501105).

\section{References}

1 X. M. Yan, Z. Mei, P. Mei, et al., J. Porous Mater., 2014, 21(5), 729-737.

2 H. Li, W. Zhu, J. Lu, et al., React. Kinet., Mech. Catal., 2009, 96(1), 165-173.

3 J. Zhang, W. Zhu, H. Li, et al., Green Chem., 2009, 11(11), 1801-1807.

4 X. Tang, Y. Zhang, J. Li, et al., Ind. Eng. Chem. Res., 2015, 54(16), 4625-4632.

5 R. Wang, G. Zhang and H. Zhao, Catal. Today, 2010, 149(1), 117-121.

6 J. M. Campos-Martin, M. C. Capel-Sanchez, P. Perez-Presas, et al., J. Chem. Technol. Biotechnol., 2010, 85(7), 879-890.

7 Z. S. Gano, F. S. Mjalli, T. Al-Wahaibi, et al., Chem. Eng. Process., 2015, 93, 10-20.

8 H. X. Zhang, H. L. Huang, C. X. Li, et al., Ind. Eng. Chem. Res., 2012, 51(38), 12449-12455.

9 S. Ribeiro, C. M. Granadeiro, P. Silva, et al., Catal. Sci. Technol., 2013, 3(9), 2404-2414.

10 H. Yang, B. Jiang, Y. Sun, et al., Chem. Eng. J., 2016, 306, 131138.

11 D. Fang, Q. Wang, Y. Liu, et al., Energy Fuels, 2014, 28(10), 6677-6682.

12 L. Lu, S. Cheng, J. Gao, et al., Energy Fuels, 2007, 21(1), 383384.

13 H. Gao, C. Guo, J. Xing, et al., Green Chem., 2010, 12(7), 12201224.
14 D. Zhao, J. Wang and E. Zhou, Green Chem., 2007, 9(11), 1219-1222.

15 A. Paiva, R. Craveiro, I. Aroso, et al., ACS Sustainable Chem. Eng., 2014, 2(5), 1063-1071.

16 C. Li, D. Li, S. Zou, et al., Green Chem., 2013, 15(10), 27932799.

17 A. P. Abbott, D. Boothby, G. Capper, et al., J. Am. Chem. Soc., 2004, 126(29), 9142-9147.

18 Q. Zhang, K. D. O. Vigier, S. Royer, et al., Chem. Soc. Rev., 2012, 41(21), 7108-7146.

19 A. P. Abbott, G. Capper, K. J. McKenzie, et al., J. Electroanal. Chem., 2007, 599(2), 288-294.

20 B. P. Wu, Q. Wen, H. Xu, et al., J. Mol. Catal. B: Enzym., 2014, 101, 101-107.

21 K. Pang, Y. Hou, W. Wu, et al., Green Chem., 2012, 14(9), 2398-2401.

22 W. Zhu, C. Wang, H. Li, et al., Green Chem., 2015, 17(4), 2464-2472.

23 Z. S. Gano, F. S. Mjalli, T. Al-Wahaibi, et al., Chem. Eng. Prog., 2015, 93, 10-20.

24 J. Yin, J. Wang, Z. Li, et al., Green Chem., 2015, 17(9), 45524559.

25 C. Mao, R. Zhao and X. Li, Fuel, 2017, 189, 400-407.

26 P. S. Kulkarni and C. A. M. Afonso, Green Chem., 2010, 12(7), 1139-1149.

27 P. Liu, J. W. Hao, S. J. Liang, et al., Monatsh. Chem., 2016, 147(4), 801-808.

28 W. Jiang, W. Zhu, Y. Chang, et al., Chem. Eng. J., 2014, 250, 48-54.

29 Y. Dong, Y. Nie and Q. Zhou, Chem. Eng. Technol., 2013, 36(3), 435-442.

30 F. Li, B. Wu, R. Liu, et al., Chem. Eng. J., 2015, 274, 192-199.

31 X. Chen, H. Guo, A. A. Abdeltawab, et al., Energy Fuels, 2015, 29(5), 2998-3003.

32 W. Jiang, W. Zhu, H. Li, et al., RSC Adv., 2013, 3(7), 23552361.

33 W. S. Zhu, H. Li, Q. Q. Gu, et al., J. Mol. Catal. A: Chem., 2011, 336(1), 16-22.

34 D. Wang, E. W. Qian, H. Amano, et al., Appl. Catal., A, 2003, 253(1), 91-99.

35 W. Zhu, H. Li, X. Jiang, et al., Green Chem., 2008, 10(6), 641646.

36 C. Mao, R. Zhao and X. Li, Fuel, 2017, 189, 400-407.

37 M. Zhang, W. Zhu, S. Xun, et al., Chem. Eng. J., 2013, 220, 328-336.

38 W. Zhu, G. Zhu, H. Li, et al., J. Mol. Catal. A: Chem., 2011, 347, 8-14. 